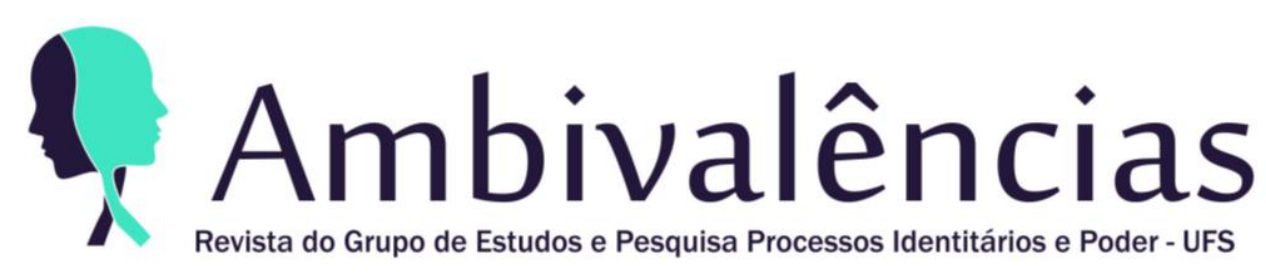

\title{
A PUBLICIDADE DE MODA COMO FERRAMENTA DE DESCONSTRUÇÃO DE PADRÕES ESTÉTICOS VIOLENTOS E COERCITIVOS NO PÚBLICO FEMININO
}

\section{FASHION ADVERTISING AS A TOOL FOR THE DECONSTRUCTION OF VIOLENT AND COERCITIVE STANDARDS IN THE FEMALE PUBLIC

\author{
LA PUBLICIDAD DE MODA COMO HERRAMIENTA PARA \\ DECONSTRUCCIÓN DE PATRONES ESTÉTICOS VIOLENTOS EN EL \\ PÚBLICO FEMENINO
}

\author{
Gustavo Presta ${ }^{1}$ \\ Ana Paula Maestri da Silva ${ }^{2}$ \\ Rafael Schultz Myczkowski ${ }^{3}$ \\ do) $10.21665 / 2318-3888 . v 9 n 17 p 292-327$
}

\section{RESUMO}

O uso do corpo na publicidade sempre exerceu grande poder sobre os consumidores e a compreensão histórica dessa relação é muito importante para entendermos essa influência e também o contexto da construção de padrões estéticos violentos e coercitivos. A publicidade tem papel fundamental na comunicação das marcas com seus públicos, pois é também através dela que os valores e posicionamento de marca são transmitidos. Por muito tempo a ideia do corpo perfeito e outros padrões estéticos preestabelecidos estiveram presentes em grande parte dos anúncios publicitários de moda. Todavia, atualmente diversas marcas utilizam a quebras desses padrões estéticos como principal forma estratégica de posicionamento. Através de pesquisa bibliográfica, documental e estudo de caso de campanhas das marcas Victoria's Secret, Nivea, Savage X Fenty e Natura, o artigo tem por objetivo avaliar se a publicidade de moda pode desconstruir os padrões estéticos violentos e coercitivos que, de certa forma, foram difundidos por muito tempo pelas próprias marcas em suas campanhas publicitárias, criando o desejo e a necessidade dos consumidores de alcançarem a beleza. Apesar de muitas marcas já procurarem reverter a visão dos corpos perfeitos, divulgando e produzindo seus anúncios sob a ótica da diversidade, talvez esteja surgindo um novo padrão de apelo comercial, mais pautado no lucro das empresas do que de fato no desejo de promoverem a inclusão dos públicos.

Palavras-chave: Publicidade de Moda. Desconstrução. Padrões estéticos. Corpo.

\footnotetext{
${ }^{1}$ Doutorando e Mestre em Artes Visuais pela UDESC. E-mail: falarcomguto@hotmail.com

2 Graduação em Design de Moda. Centro Universitário de Brusque - UNIFEBE. E-mail: anapaula.maestri@hotmail.com

${ }^{3}$ Doutor em Artes Visuais pela Universidade do Estado de Santa Catarina (UDESC). Professor do Instituto Federal do Paraná (IFPR). E-mail: rafael.s.myczkowski@gmail.com.
} 


\begin{abstract}
The use of the body in advertising has always exercised great power over consumers and the historical understanding of this relationship is very important for us to understand this influence and also the context of the construction of violent and coercive aesthetic patterns. Advertising plays a fundamental role in the communication of brands with their audiences, as it is also through it that brand values and positioning are transmitted. For a long time, the idea of the perfect body and other pre-established aesthetic standards were present in most of the fashion commercials. However, currently several brands use the breach of these aesthetic standards as the main strategic form of positioning. Through bibliographic, documentary research and case studies of Victoria's Secret, Nivea, Savage $X$ Fenty and Natura campaigns, the article aims to assess whether fashion advertising can deconstruct the violent and coercive aesthetic patterns that, in a certain way, they have been widespread for a long time by the brands themselves in their advertising campaigns, creating the desire and need for consumers to achieve the beauty. Although many brands are already seeking to reverse the vision of perfect bodies, disseminating and producing their ads from the perspective of diversity, perhaps a new pattern of commercial appeal is emerging, more based on the profit of companies than in fact on the desire to promote inclusion of audiences.
\end{abstract}

Keywords: Fashion Advertising. Deconstruction. Aesthetic standards. Body.

\title{
RESUMEN
}

El uso del cuerpo en la publicidad siempre ha ejercido un gran poder sobre los consumidores y la comprensión histórica de esta relación es muy importante para que entendamos esta influencia y también el contexto de la construcción de patrones estéticos violentos y coercitivos. La publicidad juega un papel fundamental en la comunicación de las marcas con sus audiencias, ya que también es a través de ella que se transmiten los valores y el posicionamiento de la marca. Durante mucho tiempo, la idea del cuerpo perfecto y otros estándares estéticos preestablecidos estuvieron presentes en la mayoría de los comerciales de moda. Sin embargo, actualmente varias marcas utilizan los incumplimientos de estos estándares estéticos como principal forma estratégica de posicionamiento. A través de la investigación bibliográfica, documental y casos de estudio de las campañas de Victoria's Secret, Nivea, Savage X Fenty y Natura, el artículo tiene como objetivo evaluar si la publicidad de moda puede deconstruir los patrones estéticos violentos y coercitivos que, en cierto modo, se han extendido durante un mucho tiempo por parte de las propias marcas en sus campañas publicitarias, creando el deseo y la necesidad de que los consumidores logren la belleza. Si bien muchas marcas ya buscan revertir la visión de cuerpos perfectos, difundiendo y produciendo sus anuncios desde la perspectiva de la diversidad, quizás esté surgiendo un nuevo patrón de atractivo comercial, más basado en el lucro de las empresas que en el afán de promoción. inclusión de audiencias.

Palabras clave: Publicidad de moda. Deconstrucción. Estándares estéticos. Cuerpo. 


\section{Introdução}

Pode-se considerar o início do século XX como a virada de chave para a relação do indivíduo com seu corpo, que passou a ser considerado como peça importante na construção da própria identidade e personalidade. Diversos acontecimentos no decorrer do século contribuíram para tornar o corpo um objeto de consumo e de comunicação, que sofria reflexos dos momentos vividos pela sociedade.

O mundo de imagens no qual os indivíduos foram inseridos com o advento da fotografia e das formas de reprodução, alçou as relações de necessidade e desejo a um outro patamar. Com o desenvolvimento de recursos e linguagens, as revistas de moda, filmes comerciais, novelas, anúncios publicitários segmentados e, mais tarde, o aprimoramento da tecnologia impulsionando a internet e as redes sociais, fizeram com que os consumidores dessas imagens desejassem alcançar um padrão de beleza manipulado e praticamente inatingível.

A publicidade aborda aquilo que está em pauta na sociedade, ou seja, os padrões estéticos que ela apresenta são um compilado de arquétipos que a própria sociedade cria e considera bonito. Seja de forma 'natural', advinda de aspectos culturais, ou de forma arquitetada pelos constructos simbólicos da comunicação publicitária. A beleza física se tornou um tipo de competição entre os indivíduos, valorizada como símbolo de status social. A busca pelo corpo perfeito e dentro dos padrões, portanto, fez com que os indivíduos muitas vezes sofressem consequências físicas e psicológicas.

A partir do início do século XXI algumas marcas vêm mudando o conceito de 'corpo perfeito' e empoderando mulheres para que se sintam lindas e confortáveis com o corpo que têm, para que se aceitem e possam consumir os produtos que desejam sem sentirem a necessidade de alcançar um padrão de beleza imposto pela sociedade. Por meio de campanhas e anúncios publicitários, as marcas desempenham papel fundamental na desconstrução dos padrões estéticos por muito tempo difundidos por elas, através da mesma ferramenta de comunicação, abrangendo a diversidade para atingir diferentes tipos de público. Fotos com diversos tipos de beleza feminina, mulheres negras, com 
vitiligo, acima do peso e outras, estampam capas de revistas e outros veículos de comunicação, com o objetivo de desconstruir os padrões estéticos preestabelecidos e fazer com que o público consumidor se sinta cada vez mais representado e valorizado.

O objetivo geral do presente artigo é avaliar se a publicidade de moda pode desconstruir padrões estéticos violentos e coercitivos, difundidos por ela mesma. Para tanto, foram estabelecidos objetivos específicos como descrever o papel da publicidade na construção dos estereótipos de belezas, entender as consequências físicas e psicológicas causadas em função dos padrões estéticos opressores, descrever o papel da publicidade na desconstrução dos paradigmas de beleza e analisar campanhas de moda como exemplos de construção e desconstrução de padrões estéticos.

A pesquisa pode ser considerada de natureza exploratória e descritiva. Foi utilizado principalmente o método de pesquisa bibliográfica e documental. Durante a realização do artigo foi realizado estudo de caso de desfiles das marcas Victoria's Secret e Savage X Fenty, e de propagandas das marcas Nivea e Natura para avaliar suas contribuições para a construção e desconstrução dos padrões estéticos violentos e coercitivos através da publicidade. Segundo Yin (2001, p. 32 apud PRODANOV e FREITAS, 2013, p. 61) "um estudo de caso é uma investigação empírica que investiga um fenômeno contemporâneo dentro de seu contexto da vida real, especialmente quando os limites entre o fenômeno e contexto não estão claramente definidos". No caso, a realização de análises das campanhas citadas, que aprofundam a questão da construção e desconstrução dos estereótipos.

O debate dessa temática é de grande relevância em uma sociedade em que o público vem mudando seu pensamento em relação ao corpo e às questões da moda, visando sentir-se cada vez mais representado e consumindo produtos de marcas que tenham realmente um propósito, muitas marcas já tomaram a consciência de que para sobreviverem, terão que se adaptar ao 'novo consumo'. A questão a ser acompanhada e refletida é se elas realmente desconstroem padrões, ou se trata de uma atitude apenas de viés comercial acompanhando o fluxo do mercado. 


\section{Corpo feminino e moda}

Na contemporaneidade, com a ampliação do acesso à informação e cultura global, expandido pela internet, salientam-se discursos de pontos de vistas transformadores e libertários no entendimento do corpo nas sociedades de cultura ocidental. Porém, nem sempre foi assim, principalmente com referência ao corpo feminino, quando analisado a partir da publicidade de moda no decorrer do século XX. Sabendo que a publicidade atua de modo a persuadir comportamentos de consumo, pode-se considerar que ao discurso publicitário interessa como público alvo os corpos dóceis, como compreendeu Michel Foucault (2012). Os corpos que estão prontos para serem domesticados e formatados para a assimilação de discursos persuasivos à sensação de pertencimento estimulada pelo consumo. Assim, é através da comunicação e publicidade de moda que encontra-se o espaço disciplinarizante que interessa aqui analisar. Principalmente percebendo como as evoluções tecnológicas e técnicas, no decorrer do tempo, trouxeram novas possibilidades de exploração da sensualidade e sexualidade do corpo na comunicação publicitaria, atuando como elemento de formatação, coerção e disciplinarização dos corpos na sociedade.

A cultura do consumo inseriu o indivíduo em um mundo saturado de imagens. Com isso, fez com que ele sentisse cada vez mais desejos e impôs aos corpos determinadas formas. Além de ter se tornado valor cultural, segundo Brandes e Souza (2012, p. 119), o corpo "pode ser considerado com um índice das mudanças em curso na sociedade, uma vez que absorve e reflete as informações do ambiente no qual está inserido", assumindo papéis diversos de acordo com a moda e, assim, sofrendo reflexos do que se vive em determinada época.

Durante o século XX a moda viveu intensas transformações a partir de acontecimentos marcantes como as duas grandes guerras, movimentos políticos e sociais. Com isso, o corpo também sofreu mudanças que refletiam determinados períodos. Segundo Lopes (2014), o século XX viveu o auge do corpo da moda: dietas, a ascensão dos esportes, revistas com moldes prontos de roupas, desfiles e editoriais de moda que mostravam 
modelos extremamente magras. Tudo isso teve grande influência na formação de estereótipos e na objetificação do corpo feminino.

\subsection{Facetas do corpo feminino no século $X X$}

Até o final do século XIX, segundo Alain Corbin et al. (2008), o corpo era considerado apenas um pedaço de matéria, corpo e espírito eram considerados duas coisas distintas. A virada do século XX mudou a relação entre o sujeito e seu corpo, unindo a vida espiritual e corpórea, aprofundando, assim, a questão do corpo animado como peça importante da personalidade e do comportamento.

O início do século XX, como afirmam Lobo, Limeira e Marques (2014), foi um período de muita extravagância, o que refletia também na maneira em que as mulheres se vestiam para encaixar-se nos padrões sociais vigentes, tendo em vista a continuidade do uso de espartilhos muitos justos para conferir volume ao busto e impulsionar os quadris para trás, silhueta conhecida como "S". Não apensas os modismos de vestuário condicionaram o corpo feminino, também os hábitos alimentares, a exemplo do consumo de vinagre para deixar a pele pálida e representar fragilidade e delicadeza.

Em meados da primeira década de 1900, quase ao final da chamada Belle Époque, o uso de espartilhos foi substituído por roupas mais confortáveis e feitas com tecidos leves. A marca da cintura passou para baixo dos seios e a quantidade de roupas íntimas foi reduzida. De certa forma, o conforto passou a ter alguma importância e a autonomia na ação de vestir-se ganhou espaço. Com a acessão da Primeira Guerra Mundial, percebe-se a continuidade dessa tendência, como observou Pollini (2007) ao afirmar que enquanto os homens iam para os campos de batalha, as mulheres precisaram assumir alguns cargos que antes eram apenas masculinos. Isso resultou em mudanças também na maneira de vestir, considerando o cenário político e social da época. Para Braga (2004), a necessidade que as mulheres tiveram de ocupar algumas posições dos homens durante a guerra foi o início da independência feminina, o que refletiria uma modificação mais profunda na vestimenta da classe trabalhadora, buscando a funcionalidade junto ao processo 
produtivo. De qualquer forma, esta independência concedida as mulheres visava mais a supressão de necessidades econômicas do que propriamente a conquista de direitos.

0 pós-guerra foi uma época onde o desejo por prosperidade e liberdade estavam em pauta, sendo que "as mulheres estavam cada vez mais independentes e conquistando seu espaço na sociedade. Elas passaram a lutar pelo direito de votar e decidiram derrubar antigas regras" (LOBO; LIMEIRA; MARQUES, 2014, p. 47), entre elas, a moda. A marca da cintura se deslocou para o quadril, os vestidos eram curtos, as modelagens mais retas e esconder o busto se tornou comum, algumas mulheres inclusive usavam achatadores para que parecessem ter seios menores. Passaram a usar batom vermelho, as sobrancelhas marcadas com lápis e os cabelos bem curtos. Para Braga (2004), uma certa androginia foi caracterizada às mulheres e, com isso, segundo Pollini (2007) e Vigarello (2006), logo surgiu na Europa a figura das melindrosas, conhecidas como "garçonne", que eram consideradas as mulheres modernas da época. Eram mais ousadas e ostentavam liberdade na maneira em que se comportavam. Estas mudanças de paradigma foram, por um lado, cooptadas pela publicidade e pela indústria da moda e, por outro lado, propagadas e manipuladas por elas.

Segundo Lobo, Limeira e Marques (2014), a Vogue teve sua primeira edição lançada em Nova York como um folhetim de moda em 1892. Em 1921 inaugurou a versão francesa da revista onde modelos de roupas eram publicados e as fotografias em preto e branco eram a maneira de mostrar as tendências da moda, o que, de certa forma, não valorizava algumas características da maneira mais sedutora.

Os desenvolvimentos tecnológicos da fotografia e dos meios de transmissão, que possibilitaram o uso de imagens coloridas na comunicação, influenciaram no que Corbin et al. (2008) chama de invenção do corpo no século XX. Neste sentido, afirma que:

Jamais o corpo humano conheceu transformações de uma grandeza e de uma profundidade semelhantes [...], jamais o organismo foi tão penetrado antes como vai sê-lo pelas tecnologias de visualização médica, jamais o corpo íntimo, sexuado, conheceu uma superexposição tão obsessiva, jamais as imagens das brutalidades sofridas pelo corpo na guerra e nos campos de concentração tiveram equivalente em nossa cultura visual, jamais os espetáculos de que foi objeto se aproximaram 
das reviravoltas que a pintura, a fotografia, o cinema contemporâneo vão trazer à sua imagem (CORBIN, 2010, p. 10).

A superexposição do corpo foi possível e intensificada no século XX por uma conjunção interdisciplinar de técnicas e fatores, entre eles a própria moda e o alargamento da sua publicidade, que passam a movimentar a economia e desenvolver mercados.

Com a queda da Bolsa de Valores de Nova York, a década de 1930 inicia com os ânimos mais sombrios e conservadores, porém, segundo Braga (2004), ainda assim a moda era sofisticada e luxuosa, muito influenciada pelas atrizes de cinema de Hollywood. Para Lobo, Limeira e Marques (2014), a beleza nessa época estava geralmente ligada a saúde e aos esportes. Nas revistas de moda, fotos, croquis e moldes de roupas esportivas que eram oferecidos, acabavam influenciando a produção artesanal das peças e também a prática das atividades físicas entre o público consumidor das imagens. Com a febre das práticas esportivas, a pele bronzeada entrou na moda pela primeira vez e as roupas de banho começaram a ser diminuídas, se consolidando dentro dos padrões estéticos que se estabeleciam (VIGARELLO, 2006). 0 período entre guerras evidenciou o tema da silhueta feminina e a conservação dessa forma física, passando a ser muito valorizada. 0 pouco peso passou a representar saúde, enquanto o corpo gordo era considerado não saudável. A mídia, a moda e o esporte propagaram a ideia de corpo saudável nos moldes anteriormente descritos. Neste sentido, percebe-se que este estereótipo do corpo saudável e do belo perpetuou, sendo na contemporaneidade mais explícito.

Ao final da Segunda Guerra Mundial, que foi de 1939 a 1945, a economia mundial novamente entra em crise e as mulheres mais uma vez precisaram assumir cargos dos homens no trabalho e, segundo Braga (2004), as roupas femininas acabam sendo 'masculinizadas' e os tecidos racionados. Os Estados Unidos iniciam a produção em série na moda, lidando assim com a padronização de tamanhos. Apesar de a alta-costura ter ainda permanecido, para a moda prêt-à-porter as pessoas tiveram que se encaixar dentro de determinados padrões de tamanho estabelecidos para a produção em massa das peças.

Com o intuito de salvar a indústria da moda em virtude das guerras, segundo Lobo, Limeira e Marques (2014), surgiu na década de 1940 a primeira Fashion Week, em Nova 
York, apresentando o que seria tendência para a estação seguinte. Em 1947 as cinturas marcadas, saias rodadas, sapatos de salto com bico fino e joias caracterizavam o new look de Dior, lançado para trazer de volta a ideia conservadora de feminilidade e delicadeza das mulheres. Ao longo da década de 50 popularizou-se o termo pin-ups, referindo-se a publicações em que mulheres apareciam em fotos e eram representadas em desenhos, ambos com viés erotizado, até mesmo nas situações mais cotidianas. Segundo Braga (2004), nessa época a televisão passou a influenciar muito a moda, as mulheres se espelhavam nas atrizes e em como elas se vestiam e se comportavam, dessa forma estabelecendo padrões através da comunicação.

A historiadora Denise Bernuzzi de Sant'anna (2014) explica que a moda no século XX foi muito pautada pela pose, um conceito que foi modificando-se com o tempo e passou a aparecer mais depois dos anos de 1950. Segundo a autora, uma certa rigidez da postura tem a ver com a tecnologia da época, mas também com uma mudança na noção de descontração, que é típica das décadas de 60 e 70 - quando a descontração passou a ser um valor capital. Anteriormente era reflexo de uma distinção social ser contraído, ou seja, apresentar uma postura mais ereta. No início do século os espartilhos ajudavam nessa tarefa. A ideia de um corpo rígido, ereto e vertical, se opõe ao corpo da servidão e ao corpo que se dobra, sublinhando assim as distinções sociais.

No fim dos anos de 1960, uma parte da população dos países ocidentais passou a utilizar o próprio corpo em movimentos contra os discursos de poder e "contra o peso das hierarquias culturais, políticas e sociais, herdadas do passado" (CORBIN et al., 2008, p. 8) reivindicando seus direitos. 0 corpo foi berço de transformações e considerado lugar de repressão, instrumento de libertação e promessa de revolução durante a década de 1970, marcada pela permanência do estilo hippie da década anterior.

Na década de 1980, segundo Oliveira et al. (2015), as roupas de ginástica ganharam destaque pois valorizavam as curvas conquistadas pelas mulheres, resultado dos exercícios e dietas que passaram a fazer parte do dia a dia e influenciavam suas maneiras de vestir e de se alimentar. 0 corpo magro e definido demonstrava um certo tipo de poder. 
Ao mesmo tempo em que estavam inseridas no mercado de trabalho, deveriam manter a feminilidade e sensualidade.

No decorrer do século XX as intervenções da medicina multiplicaram as possibilidades oferecidas ao corpo e "o saber médico se infiltrou no imaginário público, esclarecido por uma poderosa indústria da imagem, que concretizou os seus novos poderes. 0 próprio corpo foi profundamente remanejado pela medicina" (CORBIN et al., 2008, p. 80). Assim, principalmente as mulheres passaram a se submeter a diversos tipos de procedimentos para que se encaixassem em determinados padrões estéticos estabelecidos para agradar não apenas a si, mas a sociedade. Corbin et al. (2008) entende que na contemporaneidade o corpo acabou se tornando mais importante que a alma, e muitas vezes que a própria vida. Dessa forma, os valores morais e o bem-estar físico passaram a importar menos que a estética corporal.

O corpo 'midiático' hoje é reflexo de todas as transformações vividas pela moda e pela publicidade, principalmente durante o século XX (SANT'ANNA, 2014), que teve extrema importância na construção histórica do corpo objetificado. Tendo a sociedade disciplinar preparado e domesticado os corpos dóceis e os contextos de servidão voluntária, a comunicação publicitária de moda serviu-se dessas vulnerabilidades de forma cada vez mais intensa no sistema capitalista neoliberal. Os corpos dóceis, em busca de pertencimento, encontram-se como elucidou Foucault (2012, p. 132 e 133), presos a influências e "poderes muito apertados, que lhes impõem limitações, proibições ou obrigações. [...] não se trata de cuidar do corpo, [...] mas de trabalhá-lo detalhadamente; de exercer sobre ele uma coerção sem folga, de mantê-lo ao nível mesmo da mecânica". Movimentos, gestos e atitudes tomados como força de trabalho para o sistema capitalista mas também como potência de consumo. 


\subsection{0 papel da publicidade de moda na idealização dos estereótipos dos corpos perfeitos}

No livro "O império do efêmero", Gilles Lipovetsky (2009, p. 219) aborda que "da mesma maneira que a moda não pode ser separada da estetização da pessoa, a publicidade funciona como cosmético da comunicação". Para ele, por mais que o conceito e a criatividade sejam as chaves da comunicação, a estética ainda é vista como parte primordial no trabalho publicitário. Na publicidade em geral, mas principalmente nas campanhas voltadas para o público feminino, essa questão é observada na aparência e nos corpos das modelos, totalmente dentro dos padrões estéticos das imagens veiculadas na mídia, fazendo jus ao que a sociedade considerou belo por tantos anos, como resultado de um histórico social voltado para a construção desses padrões.

Algumas vezes o próprio público considerado fora dos padrões tem preconceito com sua aparência e deseja ver nas imagens publicitárias aquilo que gostaria de ser. "A publicidade poetiza o produto e a marca, idealiza o trivial da mercadoria. Qualquer que seja a importância tomada pelo humor, erotismo ou extravagância, a arma clássica da sedução, a beleza, não deixa de ser amplamente explorada" (LIPOVESTKY, 2009, p. 218). Dessa forma, o produto se torna interessante e desejado pelo público porque sua propaganda seduz pela alusão ao padrão de beleza estabelecido no contexto enfocado. São promessas de beleza pela sedução das aparências sem se preocupar com a seriedade da verdade, sua eficácia se liga a superficialidade lúdica, ao coquetel de imagens, de sons e de sentidos que oferece. Por toda parte se propaga a maquiagem do real e os públicos, muitas vezes sabendo da manipulação das comunicações publicitárias, entendem e vivem aquilo como 'verdade absoluta', porque as propagandas mostram aquilo que eles desejam ver. 0 espírito de persuasão presente na publicidade provém do desejo do consumidor de ser seduzido, da necessidade de ter para ser. A indução ao consumo e o status decorrente dessa realização, é devedor de práticas identificáveis no século XX, como a

difusão intensa no imaginário das massas, através da cultura e das artes populares, do sonho hollywoodiano, da arte dos ilustradores produtores de pin-up, das fotografias de estrelas, através do aporte multiforme e multiplicador da publicidade para os produtores de beleza, da 
maquiagem e da moda e, de modo geral, de tudo aquilo em que se espelha um mundo de sonho (CORBIN et al., 2008, p. 554).

Com a revolução na comunicação pela introdução de novas tecnologias, a publicidade e o consumismo se fortaleceram. O desenvolvimento da fotografia, do cinema e da televisão possibilitou a publicação de 'imagens do real' e "todo o legado cultural foi diluído num conjunto de fórmulas padronizadas, de extensão, duração e efeitos calculados" (BRANDES; SOUZA, 2012, p. 123), o que impulsionou um processo de homogeneização cultural. As aparências e visibilidades da mídia de massa, que é um dos principais meios de propagação dos estereótipos de beleza na sociedade de consumo, passaram a apresentar seu lado mais excitante para melhor vender os produtos anunciados. Nesse sentido, Sant'anna (2014) salienta que a história das imagens é também uma história cultural e tecnológica e é preciso considerar tudo isso para entender a transformação dos padrões da beleza nos últimos séculos.

Em meados dos anos 2000, as redes sociais foram tomando espaço com a popularização da internet e hoje "são usadas, não apenas para encontrar amigos, mas também para reclamar, protestar, divulgar, anunciar, etc. É como um jornal escrito por qualquer pessoa" (LOBO; LIMEIRA; MARQUES, 2014, p. 104). Isso fez com que, cada vez mais, o público tivesse acesso a imagens de pessoas 'perfeitas' nas redes sociais e também que pudessem manipular suas próprias imagens com uma facilidade enorme, através de aplicativos de edição e tutoriais. 0 nicho dos influenciadores digitais também surgiu, mostrando uma 'vida real' fácil e manipulada, aumentando o sentimento de comparação e, assim, fazendo com que o público consumidor desse tipo de conteúdo desejasse ter a mesma vida dessas pessoas.

A publicidade tem o objetivo de fazer com que o público-alvo seja de fato consumidor efetivo do produto que anuncia. Os estereótipos que emprega instauram "universos comuns de referência que correspondem a valores socialmente instituídos e partilhados" (LYSARDO-DIAS, 2007, p. 26), que geram interação tanto quando são reforçados, como quando são subvertidos. Com o passar dos anos e o desenvolvimento da sociedade, as pessoas foram se autodefinindo como partes de pertencimento a determinados grupos, seja por aproximação étnica, estética, socioeconômica, religiosa, etc. Com base nesses 
particularismos culturais que vão desde as fronteiras territoriais, passando pelas indumentárias e nuances da moda, até a comunicação social e linguagem publicitária, os seres humanos passam a viver em "comunidades imaginadas", conforme entendimento de Benedict Anderson (1983, p. 32), quando afirma que essas comunidades são condensadas em torno de símbolos que representam os elos de união entre as pessoas e as causas que simpatizam. Dessa forma, a linguagem publicitária apreendeu esse recurso no curso histórico, reconhecendo e direcionando anúncios específicos para nichos e grupos definidos como comunidades imaginadas, muitas vezes pautados em padrões estéticos violentos e coercitivos. Quanto mais conhecidas forem as referências e os estereótipos aplicados na publicidade, maior o reconhecimento pelo público consumidor e sua capacidade de captação do discurso.

O que define o consumo dos meios de comunicação de massa, para Baudrillard (2003), é a substituição do real pelos modelos de ideias produzidas. A publicidade não apresenta apenas os produtos para as mulheres cuidarem de sua aparência, mas personifica o ideal de beleza através de imagens, que encarnam os estereótipos de forma a corporificá-los. Como afirma Susan Sontag (2004, p. 177) a respeito do mundo mediado por imagens: “a realidade passou cada vez mais a se parecer com aquilo que as câmeras nos mostram". Por meio das imagens da fotografia de moda, que recria o gestual e o natural através de um processo de simulação, o corpo passa a ser objeto de desejo, em que a moda e o erótico se mesclam através de signos. Para Baudrillard (2003, p. 142) "já não é um corpo, mas uma forma", ou seja, a partir do momento em que a imagem do corpo começa a ser manipulada e transformada dentro da publicidade e também no imaginário do público, ela passa a ser uma forma criada para fins lucrativos.

Mas, Lipovetsky (2000, p. 7) postula que o grande problema da sociedade de consumo é "não conseguir incluir todos os indivíduos na sua esteira". Assim, transforma em estereótipos apenas os corpos considerados belos, a pele branca, o cabelo liso, os dentes perfeitos, o corpo magro e acaba por negligenciar o restante da população que não se encaixa nesses padrões. Segundo o autor, na era em que vivemos, de prazer e expressão de si, é preciso que se aborde menos estereótipos, e mais fantasia e originalidade. 0 atual papel criativo e conceitual da publicidade se deve às profundas transformações de 
costumes e personalidades na sociedade contemporânea, em que o indivíduo se tornou menos preocupado em exibir signos externos de riqueza e começou a busca pela autorrealização. As marcas já sentem, de certa forma, a atual mudança de pensamento do público consumidor, que hoje se atenta para imagens mais próximas da realidade em que vive. Querem consumir produtos de marcas que valorizem seu biótipo, comportamento, personalidade e incluam em suas campanhas mais do que apenas os estereótipos de beleza preconcebidos ao longo do tempo, mas todos os tipos de corpos.

\section{A ditadura da beleza e suas consequências: os padrões estéticos violentos e coercitivos}

Ao longo do tempo, cada vez mais os padrões estéticos do corpo físico se tornaram signos de competição. Sant'anna (2014) entende que, principalmente depois dos anos 80 no Brasil, salientou-se um éthos neoliberal onde ser considerado feio é ser percebido como um fracassado no governo do próprio corpo. Para a autora, essa noção caracterizou uma época contaminada pela ideia de que errar não é humano, mas errar é um fracasso. Então, desenrolou-se uma correlação entre a exigência da beleza e a exigência do sucesso: pessoas belas são bem-sucedidas, o que influencia todo mercado industrial, a economia e diretrizes das relações sociais. As qualidades morais passaram a importar menos e a 'beleza' adquirida pelo consumo se tornou forma de capital e objeto de investimentos do próprio indivíduo em seu corpo.

Para Goldenberg (2010), o corpo é capital físico, simbólico, econômico e social. Na cultura brasileira, o corpo jovem, magro, sexy, em boa forma, com cabelos lisos e dentes alinhados e alvejados é uma riqueza, um capital conquistado através de investimento financeiro, trabalho e sacrifício. Este paradigma de beleza é uma das coisas mais desejadas pelos indivíduos, que geralmente distinguem como superiores aqueles que o possuem. Sant'anna (2014) entende que historicamente a beleza sempre foi importante, principalmente para a mulher, que era considerada na sociedade como a representante da beleza. Nesse sentido, o corpo adequado aos padrões vigentes é percebido como um 
importante veículo de ascensão social. Representa sucesso em diferentes campos, como profissional, de relacionamentos, esportivo e outros.

Sant'anna (2014) afirma que no século XX houve uma progressiva preocupação com a beleza no Brasil, de modo que não ocorrera nos séculos anteriores. A presença dos produtos de beleza passou a ser muito forte, inclusive na comunicação. A publicidade e as matérias voltadas ao público feminino desencadeiam cada vez mais a questão dos padrões estéticos ao mostrarem propagandas de cosméticos, alimentos emagrecedores, dietas, suplementos, academias, truques de beleza, aparelhos estéticos, cirurgias, etc. Além de depoimentos de consumidoras que 'são mais felizes' depois que obtiveram êxito em seus tratamentos. 0 público acaba por não saber diferenciar o que é real do que é produzido pela mídia e, mesmo sabendo da manipulação de muitos anúncios que são veiculados, preferem se apegar aos falsos resultados apresentados e nas promessas de alcançarem o corpo ideal. Assim, o indivíduo massificado constantemente por mensagens publicitárias tendenciosas em um sistema de comunicação padronizante, pode sentir vontade de mudar seu corpo, pois passa a se importar com o olhar dos outros sobre si e pretende, assim, mudar sua representação e identidade.

0 fato de as mulheres geralmente quererem se sentir desejáveis e agradar ao outro, também contribui para que as mudanças estéticas - exigidas pelos padrões de beleza sejam parte importante de seu cotidiano. Exemplo disso são as mensagens publicitárias voltadas ao público masculino, como as propagandas de algumas cervejas e automóveis, que apresentam mulheres totalmente submissas e dentro dos padrões estabelecidos, ou seja, magras, de corpo curvilíneo, sem celulites e aparentemente 'sem defeitos', que aparecem como objeto de desejo dos homens.

Os estereótipos e estigmas distanciam aspectos da vida real e podem ser motores pelos quais ocorrem discriminação e preconceitos entre indivíduos e, muitas vezes, do próprio indivíduo consigo mesmo, como analisa Erving Goffman (2004) ao tratar dos estigmas sociais. Para Lysardo-Dias (2007, p. 26) “o estereótipo tem a ver com as imagens preconcebidas que se cristalizam em um grupo social e que interferem na maneira como os membros desse grupo gerenciam a convivência”. É uma questão de pertencimento do 
indivíduo em relação ao meio em que vive. A maioria das mulheres, geralmente nunca satisfeitas frente as ondas de novidades trazidas pela indústria do consumo, se encontra em uma busca constante pelo embelezamento e corpo perfeito, dos estereótipos da época.

Junto com a comunicação de massa, a moda tem grande participação no fomento dos padrões de beleza, principalmente referentes aos ideais de corpo, exibindo modelos macérrimas. Esse ideal imagético não atinge só o público consumidor das imagens, mas também as próprias modelos. Foi assim que a anorexia nervosa, por exemplo, invadiu as passarelas. Além disso, a imposição das imagens idealizadas por muitas décadas no cotidiano das mulheres causou efeitos psicológicos que contribuíram para o transtorno dismórfico corporal4 em muitas consumidoras. Em função disso e do descontentamento com a própria aparência, cada vez mais cresceram os números de cirurgias estéticas e casos de anorexia e bulimia, causados pelos distúrbios de imagem corporal.

\subsection{Como as campanhas publicitárias estimulam padrões estéticos}

Os contextos da beleza são essenciais para perceber a construção da subjetividade na época contemporânea no Brasil (SANT'ANNA, 2014). Quando se fala sobre a construção dos padrões estéticos violentos e coercitivos é importante apontar as ações de comunicação publicitárias, que por anos exaltaram um único padrão de beleza feminina na sociedade. Na moda, porém, muitas vezes esses padrões foram mais impactantes que em outros segmentos, influenciando muitas pessoas e auxiliando no processo de naturalização da aceitação dos padrões, em detrimento da valorização da diversidade.

4 Doença psicológica com foco obsessivo em um 'defeito' na própria aparência. 


\subsubsection{Victoria's Secret Fashion Show}

Segundo Chitas (2016), a marca Victoria's Secret foi criada em 1977 e é conhecida mundialmente por suas lingeries e cosméticos. Ao analisar o histórico de desfiles e da comunicação da marca, percebe-se que ao abordar a questão do corpo aparente, ela faz jus aos padrões estéticos vigentes, caracterizando a mulher-objeto que teve sua imagem construída no decorrer dos anos, criando uma certa coerção das consumidoras em relação ao próprio corpo.

O Victoria's Secret Fashion Show (VSFS) 2018 (Figura 1), último desfile da marca apresentado até o momento da realização dessa pesquisa, segue o mesmo padrão desde o primeiro VSFS, realizado em 1995, sendo que o evento passou a ser televisionado a partir de 2001.

Figura 1: Victoria's Secret Fashion Show 2018

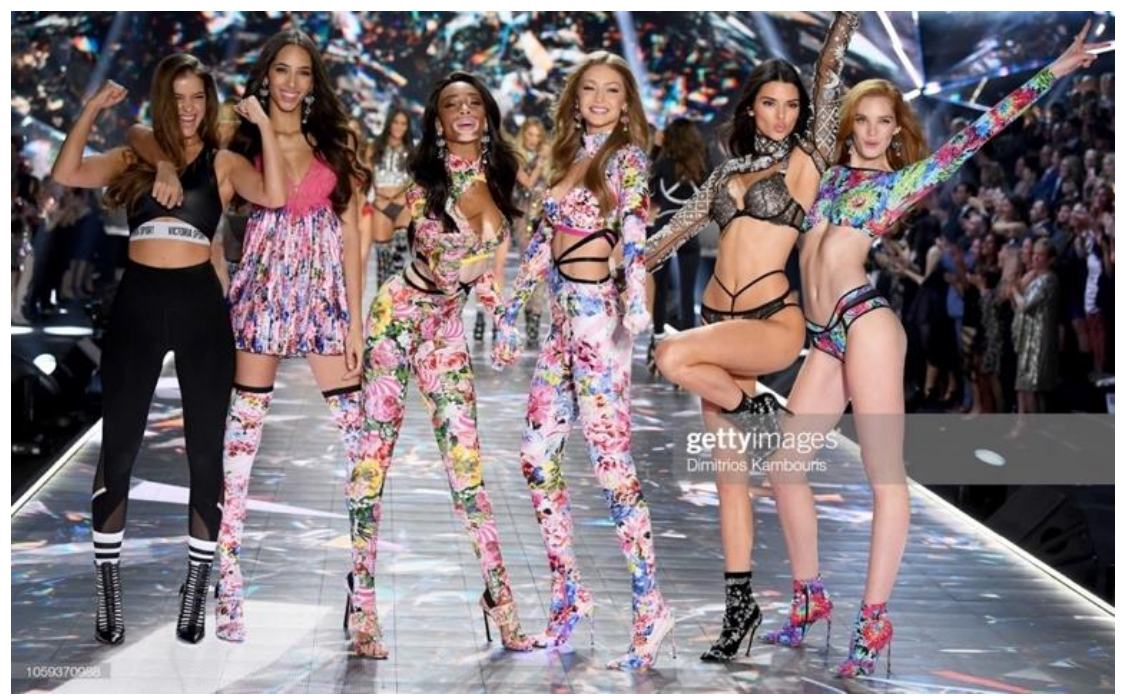

Fonte: Dimitrios Kambouris/Getty Images for Victoria's Secret

O elenco continua nos mesmos padrões que teve desde o início, composto por mulheres altas, magras, majoritariamente brancas, com cabelo liso ou levemente ondulado e impecável, dentes brancos e alinhados em um sorriso simpático, desfilando lingeries luxuosas e sensuais em cima de um salto alto. Apesar da escolha do elenco do desfile tentar inspirar uma certa diversidade com modelos asiáticas e negras, incluindo Winnie Harlow (Figura 1, terceira modelo da esquerda para a direita), primeira modelo com 
vitiligo ${ }^{5}$ da história, a marca geralmente apresenta na passarela o que se pode considerar como falsa diversidade, pois mesmo com diferenças étnicas, todas as modelos ainda apresentam um padrão corporal homogêneo praticamente inatingível e extremamente sexualizado. Todas as modelos têm o mesmo biotipo, os corpos são todos muito semelhantes e os trejeitos interpretativos bastante sensuais. Até mesmo Winnie Harlow que por ter vitiligo é considerada um exemplo de diversidade na moda - é magra, alta, desfilou no VSFS com o cabelo liso e comprido, paramentada de adornos luxuosos, totalmente dentro dos padrões estéticos estabelecidos.

O show televisionado mostra também momentos dos bastidores, dos castings e a preparação das modelos, que se inicia um mês antes do dia do desfile. Apesar de todas já terem um lifestyle de dietas e academia, é nesse tempo que pegam mais pesado em busca das metas estabelecidas pela marca. 0 especial de TV mostra cenas da dedicação das modelos na academia nos 30 dias que antecedem o desfile, dessa maneira também exploram a sensualidade e sexualidade implícita no estilo de vida utópico, reforçando a ideia de que corpo bonito é apenas o corpo magro, alto, resultado de sacrifícios, dietas e treinos pesados, a despeito de problemas de saúde ou questões genéticas que possam acometer as pessoas em geral. Todas as modelos têm o comportamento confiante na passarela e aparentam estar muito felizes, o que passa a falsa ideia de que a beleza está relacionada a felicidade, ainda que casos de assédio contra modelos6, privações alimentares7 e depressão8 estejam entre as ações contra a marca.

Levando em conta que a beleza virou símbolo de disputa entre grande parte dos indivíduos (VIGARELLO, 2006), pode-se considerar o próprio casting para a escolha das modelos que vão desfilar no Show, uma espécie de competição. Entram para o elenco as que têm o corpo mais adequado ao padrão abusivo apresentado pela marca, atitude e

\footnotetext{
5 Doença que causa a perda gradativa da pigmentação da pele.

6 Disponível em: https://www.metropoles.com/colunas-blogs/ilca-maria-estevao/modelos-pedematitude-da-victorias-secret-contra-casos-de-assedio . Acesso em 25.05.2021.

7 Disponível em: https://www.theguardian.com/fashion/2016/apr/07/my-agents-told-me-to-stopeating-the-reality-of-body-image-in-modelling . Acesso em 25.05.2021.

8 Disponível em: https://gauchazh.clicrbs.com.br/donna/gente/noticia/2016/04/top-erin-heathertonconta-que-saiu-da-victoria-s-secret-porque-recebeu-ordens-para-emagrecercjqxxut760068p9cnr2gp08em.html. Acesso em 25.05.2021.
} 
comportamento sensual, ou seja, as que têm as características dos padrões estéticos físicos e comportamentais vigentes.

Quando perguntado sobre a falta de diversidade no show, Ed Razek, diretor de marketing da Victoria's Secret, disse que não achava que o desfile deveria ter modelos transexuais ou plus size porque ele representa uma fantasia, é um especial de entretenimento (GARDNER, 2019). Após a contratação de uma modelo transexual brasileira em 2019, Razek pediu demissão do seu cargo na companhia. O VSFS 2019 foi cancelado em razão de diversas críticas sofridas justamente pela falta de diversidade na passarela, o que pode representar a necessidade de um reposicionamento da marca.

Como parte das ações de comunicação, os desfiles anuais da Victoria's Secret, desde 1995, contribuíram para a construção de um padrão de beleza restrito e praticamente inatingível. 0 corpo das modelos foi desejo de consumo das mulheres que absorviam as imagens e mensagens publicitárias. Assim, através de marcas como a Victoria's Secret, que salientavam um único padrão estético a ser imposto à sociedade, muitas mulheres podem ter sido influenciadas a submeter-se a diversos tipos de procedimentos estéticos e até desenvolveram doenças psicológicas em busca do corpo perfeito.

\subsubsection{Nivea "Para uma pele visivelmente mais clara"}

Segundo a BBC News (2017) a marca Nivea, da empresa alemã Beiesdorf, veiculou uma campanha no ano de 2017 nos países africanos Nigéria, Gana, Camarões e Senegal, com o seguinte slogan: "Para uma pele visivelmente mais clara", que divulgava o hidratante "Natural fairness", que significa "clareza natural". A estrela da campanha foi a ex-miss Nigéria Omowunmi Akinnifesi, a qual aparecia em outdoors pelas cidades (Figura 2) e comerciais de TV9 mostrando como sua pele tornou-se mais clara após a aplicação do creme.

9 Disponível em: instagram.com/p/BaYxGenHrEY/?utm source=ig embed . Acesso em: 25.05.2021. 
Figura 2: Outdoor da campanha Nivea "Para uma pele visivelmente mais clara".

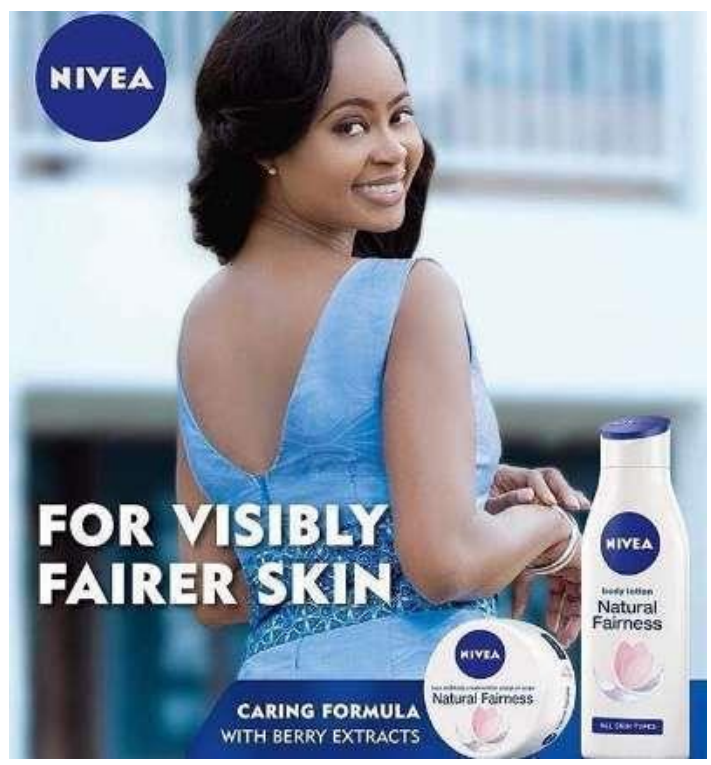

Fonte: Daily PR Africa.

Apesar de o produto não ser novo no mercado, a campanha de divulgação rendeu críticas à marca. $\mathrm{O}$ uso da imagem de uma modelo negra com boa aceitação social querendo 'clarear' o tom da sua pele repercutiu negativamente, não apenas nos países em que a campanha foi veiculada, considerando que são países de maioria negra, mas também em outros países, graças a repercussão na internet. A campanha fazia alusão ao padrão de pele clara e indiretamente afirma que a pele branca é mais bonita que a pele negra, insinuando que os africanos gostariam de adquirir o produto da marca para se encaixar nos padrões de beleza brancos eurocêntricos. Este processo de branqueamento, recorrente e manifesto de diferentes formas na história da humanidade, parece sempre retornar explicita ou implicitamente, mostrando como a concepção de superioridade branca permanece no imaginário social.

A propaganda pode atingir um público maior de mulheres, por não compactuar com o padrão de mulher macérrima e sim apresentar um corpo mais curvilíneo. Apesar disso, considerando que a estrela da propaganda é ex-miss Nigéria, pode-se entender que ela foi considerada uma das mulheres mais bonitas do seu país, o que acaba reforçando um padrão estético cultural. 
O audiovisual dá ênfase à pele da mulher que, ao sair do banho, passa o creme clareador de forma a relacionar o produto à sensualidade. Depois disso, ao buscar a filha na escola, visivelmente feliz e usando um vestido com decote nas costas, que valoriza as curvas do corpo, ela atrai o interesse de um homem que passa e se surpreende quando a criança a chama de 'mãe', o que remete a jovialidade e ao 'glow' da pele clara que o produto promete.

Até mesmo em países de maioria negra, seja no continente africano, mas também no Brasil, a mídia difunde determinados padrões de beleza vigentes em outras partes do mundo, de certa forma ignorando a diversidade cultural que existe entre os países e difundindo a homogeneização estética do padrão de beleza da globalização, de interesse das grandes marcas que realizam processos de comunicação integrada global. Segundo a BBC News (2017), estudos apontam que muitas mulheres em África fazem uso desse tipo de creme clareador de pele, o que já pode ser identificado como reflexo dos padrões estéticos preestabelecidos e disseminados na era da comunicação digital.

Os exemplos apresentados, ambos de produtos voltados ao consumo feminino e que exploram o corpo em suas dinâmicas de comunicação mais tradicionais, corroboram com a noção de que na contemporaneidade, aproximadamente desde a década de 1990, o padrão de comunicação ocidental com foco na globalização vem sendo pautado pelo uso de padrões estéticos de beleza violentos e coercitivos que implicam diversas consequências sociais e culturais.

\subsection{As consequências dos padrões estéticos impostos}

Os padrões estéticos impostos pela sociedade e pela comunicação midiática aqui apresentados ocasionam nas mulheres (e não apenas nelas) uma série de problemas psicológicos e, assim, o desejo de alterações físicas relacionadas a aparência para que se sintam pertencentes a grupos determinados. 
Conforme Honorato (2018), estatísticas da Sociedade Brasileira de Cirurgia Plástica revelaram que o Brasil já ultrapassou os Estados Unidos em intervenções cirúrgicas estéticas realizadas em adolescentes. Segundo o chefe da Divisão de Cirurgia Plástica do Hospital das Clínicas da Faculdade de Medicina de Ribeirão Preto (HCFMRP) da USP, Jayme Farina Junior apud Honorato (2018), enquanto nos Estados Unidos 4\% das cirurgias estéticas foram realizadas em adolescentes, o que corresponde a 66 mil cirurgias, no Brasil o número ultrapassou 90 mil. Esses números podem ser considerados reflexos da cultura do culto ao corpo, cultivada desde cedo na população e que incentiva esse tipo de procedimento.

Segundo a Sociedade Internacional de Cirurgia Plástica Estética - ISAPS (2018) - as mulheres são responsáveis por 84\% dos procedimentos estéticos em todo o mundo e entre os procedimentos cirúrgicos mais populares estão o implante de próteses de silicone nas mamas, lipoaspiração, blefaroplastia ${ }^{10}$, abdominoplastia e mastopexia ${ }^{11}$. Como toda cirurgia, as que tem apenas fins estéticos também oferecem riscos à saúde dos pacientes. Através de um estudo feito com membros da Sociedade Brasileira de Cirurgia Plástica (SBCP) em 2015, foi relatado que 33,6\% dos cirurgiões tiveram intercorrências em cirurgias de lipoaspiração e 5,4\% evoluíram para óbito per ou pós-operatório. Ainda assim, muitas mulheres se submetem a esse tipo de procedimento e riscos, apenas em função da estética do corpo.

Conforme visto, a marca Nivea lançou em 2017 um anúncio sobre seu creme clareador de pele. Apesar de ter sido uma propaganda polêmica, segundo a BBC News (2017), uma pesquisa da Organização Mundial da Saúde (OMS) revela que 77\% das mulheres na Nigéria fazem uso regular de clareadores. De acordo com um estudo da Universidade da Cidade do Cabo, na África do Sul uma em cada 3 mulheres também utiliza esse tipo de produto, que pode causar câncer.

Além das cirurgias estéticas e produtos, outro fator relevante são as doenças e transtornos causados em decorrência do culto ao corpo. A anorexia e a bulimia, por exemplo, são

10 Procedimento realizado nas pálpebras. 11 Levantar ou mudar a forma dos seios. 
patologias psiquiátricas que a pessoa desenvolve e acaba expressando no próprio corpo. Quem sofre desses transtornos geralmente não acha que seu comportamento é prejudicial à saúde, pois, apesar da perda de peso excessiva, continua se achando acima do peso, o que é um efeito conhecido como distorção de imagem corporal.

Para combater essa problemática, durante a Semana de Moda de Milão, em setembro de 2007, uma campanha publicitária criada pelo fotógrafo Oliviero Toscani mostrava uma modelo nua, pesando apenas 31 quilos, com o título "No anorexia"12. Os dois modelos de outdoor (Figura 3) causaram impacto no público consumidor da Semana de Moda, e também em modelos e estilistas da Europa, pois mostrava a cruel realidade por trás dos desfiles e dos corpos exauridos das modelos, que se obrigavam a seguir um padrão rigoroso imposto pelas marcas, com consequências muitas vezes ignoradas e banalizadas.

Figura 3: Outdoors da campanha criada por Oliviero Toscani.

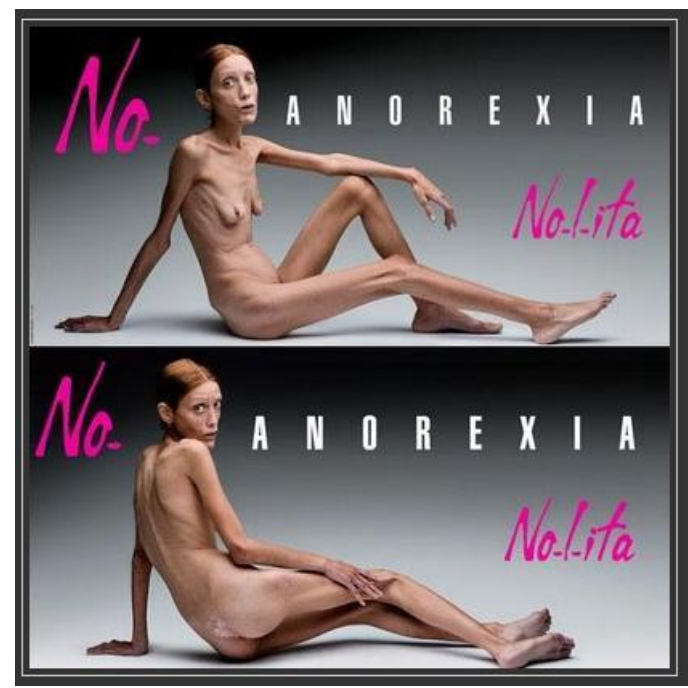

Fonte: SANTOS (2007)

Assim, o culto ao corpo, toda a obsessão pela beleza e juventude e todas as práticas e sacrifícios realizados pelas pessoas, para Baudrillard (2003, p. 136), "testemunha que o

12 Em tradução livre: "não anorexia” 
corpo se tornou objeto de salvação. Substitui literalmente a alma, nesta função moral e ideológica" na busca da realização física e estética para si e para o outro.

\section{Publicidade e desconstrução dos padrões estéticos}

Além da construção dos estereótipos, segundo Lipovetsky (2000), moda e publicidade também passaram por um processo evolutivo que resultou positivamente na liberação das mulheres. A sedução passou de um padrão único de beleza para o pensamento de que cada mulher é bonita e sedutora do seu jeito, com seu corpo e sua atitude. Para Sant'anna (2014), a liberação feminina ocorreu paralelamente a uma modificação no padrão de beleza recente, assimilando e fortalecendo a questão da moralidade.

Reiterando essa ideia, Silva (2014) afirma que no início do século XXI, através de influências sociais, a publicidade passou a valorizar a diversidade dos corpos, em oposição aos estereótipos de beleza estabelecidos anteriormente pela própria sociedade. Ou seja, do mesmo jeito que os discursos publicitários participaram da construção de estereótipos, também sentiram a necessidade de se reestruturar para desconstruí-los, mesmo que de forma mínima e muitas vezes contraditória. "A visibilidade do diferente na publicidade está intrinsecamente relacionada à presença destes corpos na sociedade" (SILVA, 2014, p. 8), afinal, à medida que novas gerações vão surgindo e novos acontecimentos sociais e econômicos moldam a compreensão do mundo, as formas de consumo e os próprios consumidores mudam seu pensamento e, se articuladas novas posições éticas, começam a cobrar das marcas um posicionamento mais inclusivo e pertinente às características existentes na sociedade.

0 fato de o consumidor 'real' querer se sentir representado, acabou "exigindo que o pensamento fosse reformulado em adequação aos novos termos, para poder interagir com o novo contexto" (BRANDES; SOUZA, 2012, p. 122). Ou seja, as marcas sentiram a necessidade de se posicionarem em relação a diversidade de corpos que a sociedade apresenta, para que se mantenham no gosto do consumidor hiperconectado e engajado 
na internet, que considera ultrapassado o estereótipo único de beleza tão difundido pela moda e pela publicidade durante o século XX.

Segundo Lysardo-Dias (2007), a publicidade mantém fatores comuns entre o antigo padrão e os novos modelos que surgem pois, dessa forma, a imagem não perde alguns de seus traços tradicionais e não fica totalmente irreconhecível. Não subverte efetivamente o modelo antigo, em função da pretensão comercial em que se baseia. Ou seja, mesmo que exista uma intenção real de contribuir para a desconstrução de certos padrões, o objetivo de cativar o público através do que ele deseja ver é, no fim, uma prospecção comercial, afinal, as marcas precisam vender. A presença do 'diferente' na publicidade atrai o consumidor justamente por fugir das características dos padrões estéticos que por anos monopolizaram as mídias.

A nova forma de pensar do consumidor, que tem mais acesso às ferramentas de comunicação que abriram diálogo direto com as marcas, é pautada na compreensão do desejo de representatividade e inclusão dos corpos 'não perfeitos' que compõem a maioria da sociedade. A internet e as redes sociais deram acesso a informações que antes não eram de conhecimento facilitado, o que acabou exigindo das marcas um aperfeiçoamento do processo de humanização e veracidade com que tratam seus sistemas produtivos e de comunicação.

Apresenta-se um paradoxo pois, ao mesmo tempo que determinadas empresas e campanhas publicitárias cooptam corpos dissidentes e monetarizam a representatividade, pode-se considerar que de fato existe um caráter transgressor quando a publicidade apresenta corpos diferentes, diversificando e testando os padrões difundidos anteriormente. "Ela reforça esse papel quando sua mensagem de objetivo eminentemente comercial tem um forte impacto no espaço cultural" (LYSARDO-DIAS, 2007, p. 33), o que também pode impactar positivamente a sociedade. 


\subsection{A ruptura dos estereótipos pela publicidade}

Ao abordar a questão da desconstrução dos padrões de beleza na atualidade, muitas marcas ainda se recusam a incluir em suas campanhas tipos de beleza fora dos padrões estéticos vigentes, como a Victoria's Secret, entendida na análise anterior como uma marca que ajudou a construir um estereótipo de corpo perfeito. 0 cancelamento do desfile da marca em 2019, em decorrência das diversas críticas que vinha recebendo com relação ao seu comportamento considerado ultrapassado na passarela e na sua forma de comunicação, que vai contra o sentido que segue o mundo da publicidade contemporânea, representa a mudança de pensamento do consumidor com o surgimento das novas gerações.

\subsubsection{Análise do desfile Savage X Fenty Show 2019}

Na contramão da Victoria's Secret, em 2018 foi criada a Savage X Fenty - marca de lingerie da cantora Rihanna - que se propõe a celebrar a diversidade no mundo. A lingerie, por representar a autoestima da mulher que a veste e ser o tipo de peça que deixa o corpo a mostra, explora, em sua maioria, a sensualidade feminina. Por muito tempo as lingeries foram desenhadas sob a ótica masculina, para que agradassem aos homens, porém a proposta da marca Savage X Fenty é de que as mulheres as usem para elas mesmas, para que se sintam lindas, sexy e confiantes do jeito que são. Os tamanhos vão de 32A a 46DDD para sutiãs e de XS a 3X nas partes de baixo e, além das modelagens grandes para corpos diversos, também apresenta preços acessíveis.

A segunda edição do Savage X Fenty Show (Figura 4) aconteceu em 10 de setembro de 2019, no Barclays Center, no bairro Brooklyn, durante a semana de moda de Nova York. Apresentou a coleção de outono/inverno da marca e foi muito bem comentado pela mídia por representar a diversidade em um espetáculo que misturou moda, música e teatro. 
Figura 4: Momento da Savage X Fenty Show 2019.

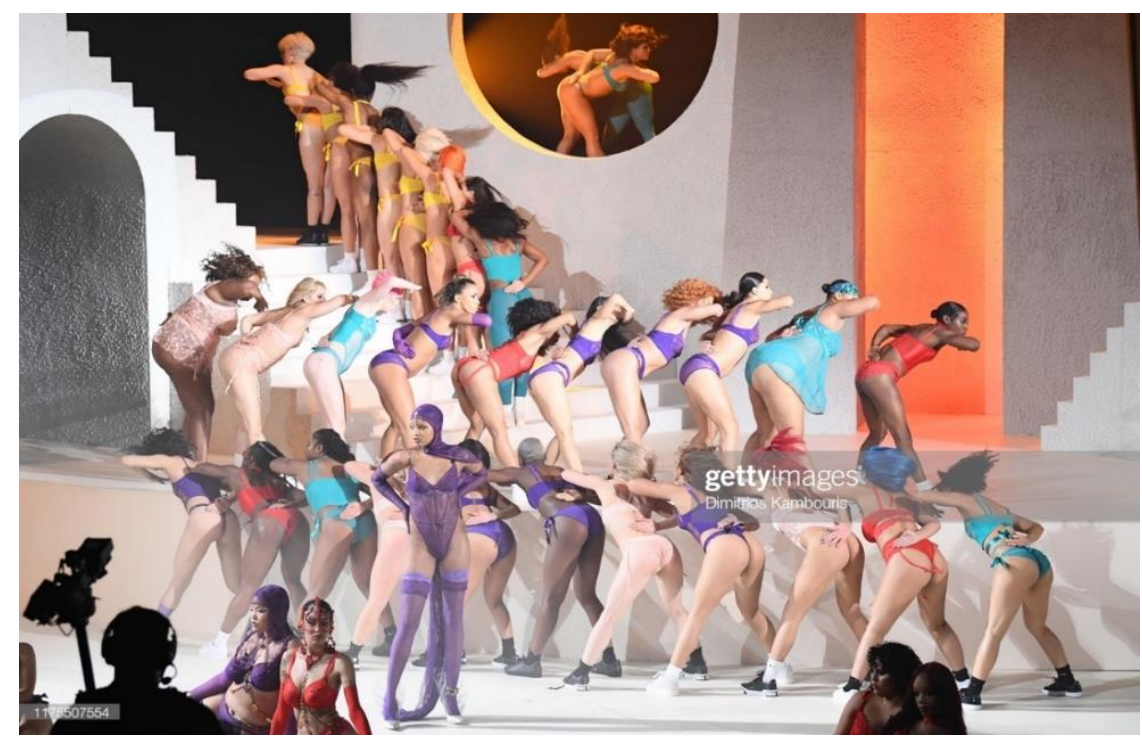

Fonte: Dimitrios Kambouris/Getty Images para Savage X Fenty Show.

O formato do desfile foi totalmente diferente da convencional passarela das fashion weeks. No documentário Savage X Fenty Show (2019), Rihanna diz que procurou para o elenco do desfile pessoas com características únicas, que geralmente não são evidenciadas no mundo da moda, principalmente em relação as lingeries e sobre o que a sociedade entende como sexy. No documentário, Jennifer Rosales (2019), Senior VP da marca, afirma que "não existe um público-alvo, é para todos. Ela (Rihanna) quer que todos se sintam bonitos, que todos se sintam empoderados, que todos sintam e tenham essa força para se tornarem a melhor versão de si mesmos."

A coreografia inicial do show tem Rihanna e algumas bailarinas usando a mesma roupa, gordas, magras, de cabelo liso, cacheado, brancas ou negras, ou seja, não importa a aparência, todas vestem o mesmo modelo, o que representa igualdade. Além das modelos e bailarinas fora dos padrões, também participaram do show modelos como Gigi e Bella Hadid e Cara Delevigne, que já desfilaram no Victoria's Secret Fashion Show e têm o corpo totalmente dentro dos padrões estéticos difundidos por tanto tempo na publicidade de moda. Ao participarem do desfile e usarem as mesmas roupas que as modelos de outros biotipos, representa que a marca pretende alcançar diversos tipos de corpos, sem 
exclusão ou preconceito. 0 fato de as peças da coleção serem disponibilizadas em tamanhos não convencionais fomenta a adesão do público à marca em uma relação de respeito, além de empoderar públicos que geralmente não se encaixam nos tamanhos das marcas consideradas as mais sexy do mercado. Segundo Rihanna (2019), a marca explora vários biotipos para "as mulheres não se sentirem excluídas apenas porque são de tamanhos diferentes." Afinal, é um desfile de inclusão e o objetivo dele é mostrar igualdade com a ideia de que um modelo sexy de lingerie não é feito apenas para mulheres magras ou formatadas em determinados padrões.

Além da diversidade de corpos presentes na 'passarela', durante todo o desfile tocam músicas que vão de ópera a funk brasileiro, o que valoriza também a diversidade cultural. A estrutura e o cenário da apresentação são bem preparados e tem um formato bem diferente do comum dos desfiles de moda. Praticamente em todos os momentos são apresentadas coreografias de dança, todas ensaiadas e executadas por bailarinos com diversos tipos de corpos mostrando sensualidade, positividade, inclusão e habilidades corporais. A maioria do elenco usa tênis ou sandálias sem salto, com exceção de algumas modelos, o que também quebra o paradigma de que as mulheres têm que se forçar a usar salto alto para que sejam consideradas bonitas ou bem vestidas. A ideia é que se sintam confortáveis tanto com a aceitação das suas aparências, quanto com as roupas que vestem.

Todas as modelos apresentam expressões marcantes, representam estar felizes e tem comportamento confiante e empoderado. Para Rihanna (2019), como o principal objetivo da Savage X Fenty é a inclusão, "é muito importante que o elenco conte a narrativa do que a marca representa". Por isso é tão importante que as modelos se sintam elas mesmas e transpareçam isso durante a apresentação, para que o público consiga captar a energia do espetáculo e para que o posicionamento da marca se estabeleça na mente do consumidor.

\subsubsection{Análise da campanha Natura "Sou mais que um rótulo"}

Quando o assunto é campanha publicitária de cosméticos, geralmente as promessas centrais são de usá-los para exaltar a beleza e se adequar aos padrões estéticos vigentes, 
normalmente representados pelas modelos dos comerciais, que têm a pele saudável e uniforme, sorriso e cabelos reluzentes e o corpo sem celulites ou estrias. Porém, algumas marcas que prezam pela diversidade cada vez mais trabalham para desconstruir padrões em suas campanhas, aproveitando o impacto de suas ações sobre o público. A Natura, por exemplo, já tem um histórico de campanhas que celebram a diversidade, não só de corpos, mas de gêneros e orientação sexual, como a campanha da "Coleção do amor"13 (2019), da linha de maquiagem Natura Faces, que apresenta três casais de mulheres contando suas histórias. A repercussão nas redes sociais foi marcada por críticas positiva e negativas, pois nem todo público tem consciência ou está preparado para absorver certos tipos de conteúdo.

A campanha Natura "Sou mais que um rótulo"14, de agosto de 2019 - apresentada por personalidades como a atriz Cléo Pires, a cantora Iza, a lutadora Kyra Gracie e outras mulheres brancas, negras, magras, gordas, de cabelo curto, comprido, loiro, moreno, colorido, ruivo, liso, cacheado, com perna mecânica e tatuadas - aborda a diversidade de corpos existentes além dos rótulos e estereótipos (Figura 5). A ideia da propaganda é promover uma linha de produtos que se adapta as necessidades de cada pele. Ou seja, não importa como é o seu corpo, o que você faz, se você está ou não dentro dos padrões estéticos estabelecidos, a linha é para todos. A campanha foi produzida em estúdio, onde o fundo e as roupas usadas pelas modelos são do tipo "segunda pele" em tons terrosos e rosados, criando harmonia ao contexto da peça e abordando a questão dos diferentes tons e tipos de pele, que é a real intenção da propaganda, ou seja, o foco está na diversidade apresentada.

13 Disponível em: https://www.youtube.com/watch?time continue=80\&v=c0FUG-9iACQ . Acesso em 25.05.2021.

14 Disponível em: https://www.youtube.com/watch?v=iIAP9ZUM8yg . Acesso em 25.05.2021. 
Figura 5: Campanha Natura "Sou mais que um rótulo".

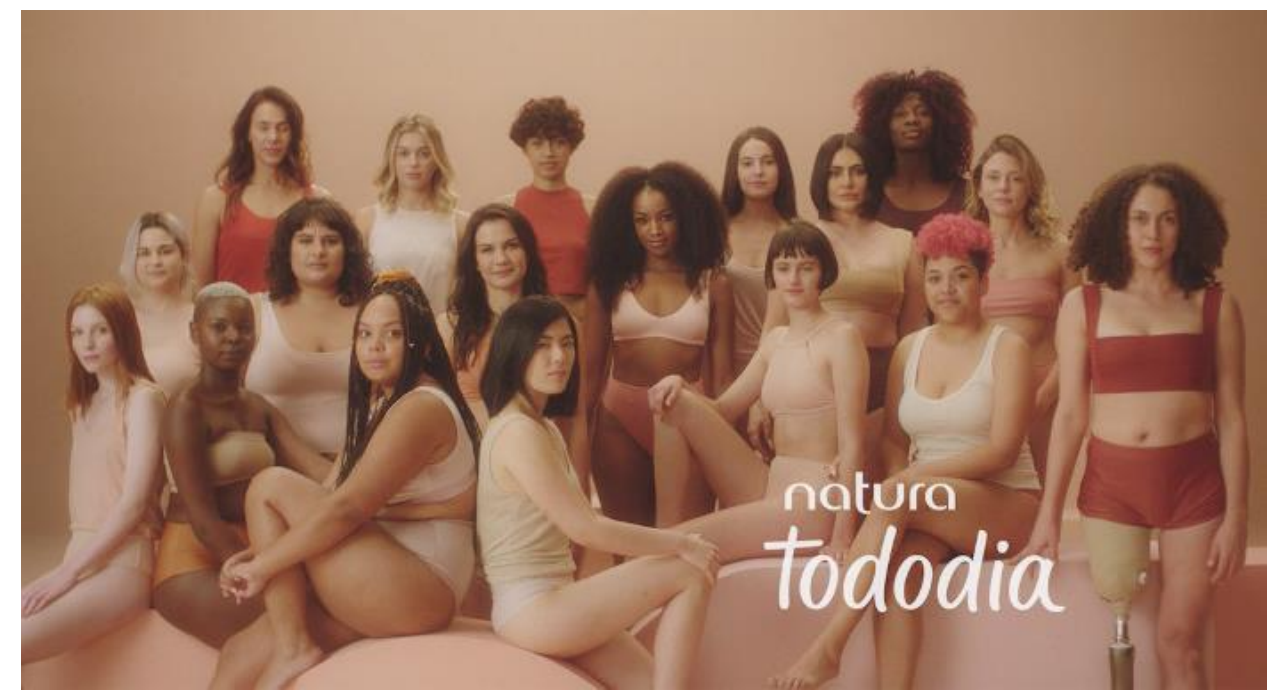

Fonte: Promoview (2019).

No início da peça a narrativa é de que ser mulher é desafiar rótulos, é ser muito mais do que apenas uma definição, é viver mudando. Enquanto isso, adesivos com palavras como "mal resolvida", "previsível", "irritada" e "durona" que estavam colados nos corpos das mulheres como rótulos, vão sendo retirados por elas mesmas, o que representa uma espécie de libertação dos padrões que por tanto tempo lhes foram impostos. Representa a coragem de se aceitarem e assumirem seus corpos do jeito que são, instigando as mulheres a dominarem a própria existência e se livrarem de determinados rótulos. Estabelece também que uma mulher pode mudar seu pensamento e seu corpo quando achar que precisa ou deseja, fazendo alusão aos padrões estereotipados de beleza que por tanto tempo couberam às mulheres e hoje passaram a não mais representá-las.

Deve-se observar que é uma campanha bem produzida, as modelos são maquiadas, os ângulos e enquadramentos de câmera são roteirizados de acordo com a mise-en-scène, como qualquer outra propaganda com a intenção de vender e promover sua marca. Mas possibilita que as mulheres do outro lado da tela se reconheçam e também se sintam representadas. Ainda assim, mesmo sendo uma campanha contra rótulos, a atriz Cleo Pires foi chamada pejorativamente de gorda nas redes sociais, mostrando que ainda há um longo caminho a se percorrer com relação à aceitação do público, em geral para as propostas de comunicação que pretendem quebrar alguns estereótipos. 
Mesmo com cunho comercial e mantendo a ideia do cuidado ao corpo com os produtos Natura, a propaganda não expõe o produto diretamente, ou seja, dá muito mais ênfase de fato ao conceito e a ideia da propaganda, que é exaltar os diferentes corpos e belezas que existem, o que, no fim, pode resultar no reconhecimento e simpatia do público pela marca e, assim, na adesão aos seus produtos.

\section{Considerações finais}

Como visto, o corpo é fundamental no que diz respeito a relação do indivíduo com o mundo a sua volta. Sabendo que o corpo pode ser compreendido sob variadas dimensões e correntes de pensamento, interessou à pesquisa considerá-lo com base no entendimento dos corpos submissos, articulados com a linguagem publicitária, processos de consumo e integrados ao sistema social de cultura ocidental capitalista e neoliberal. Nesse sentido, o corpo é agente e reflexo dos momentos vividos na história, principalmente no decorrer do século XX, que contribuíram para sua exploração como objeto de consumo e comunicação, até chegar à complexidade que representa hoje. 0 surgimento das imagens publicitárias, que aumentaram gradativamente com o passar dos anos, e a inserção do corpo como principal elemento de persuasão, fez com que ele se tornasse objeto de desejo, principalmente das mulheres, que passaram a comparar seus corpos com os vistos nas propagandas. Dessa forma, os padrões estéticos ficaram cada vez mais em evidência.

Com a chegada do século XXI, a mulher passa de mulher-objeto para mulher sujeito, conquista cargos políticos e na direção de empresas, e tem mais liberdade do que já vinha conquistando no decorrer do século XX. Os valores e as características culturais sofrem transformações constantemente e a publicidade reflete isso na personificação dos padrões vigentes.

Com o surgimento da internet e a ascensão das redes sociais, as pessoas tiveram, além da publicidade, cada vez mais acesso a imagens de corpos perfeitos e aparentemente inatingíveis, mesmo que muitas vezes fossem manipuladas por recursos e aplicativos para 
que ficassem mais próximas dos padrões estabelecidos. Ao se comparar com as imagens que consome, o público pretende alcançar determinados estereótipos para que se sinta parte de um grupo, além de estabelecerem uma falsa relação entre padrões estéticos e felicidade. Dessa forma, a comunicação pela internet intensificou e massificou os estereótipos de beleza violentos e coercitivos, que já vinham se estabelecendo na publicidade em geral, em especial na publicidade de moda e cosméticos, como visto na análise das ações de comunicação das marcas Victoria’s Secret e Nivea. Porém, ao mesmo tempo a internet também contribuiu para a desconstrução de muitos estereótipos, democratizando o acesso a produtos e comunicações de marcas que passaram a apostar na diversidade em suas campanhas publicitárias, como a Savage X Fenty e a Natura, conforme visto nas análises anteriores.

As redes sociais possibilitaram a exploração da comunicação de grandes empresas de uma forma mais orgânica e que se conectassem de forma mais intensa com o público real das marcas. Também deram chance a inúmeras marcas, que surgiram com o propósito da quebra de padrões, de se comunicarem com seu público, pois mesmo marcas pequenas já nascem atualmente com a consciência de que o consumidor está mudando seu pensamento no que diz respeito aos estereótipos de corpos perfeitos e as novas formas de consumo. 0 público, antes submisso aos padrões de beleza, quer se sentir cada vez mais representado, portanto, as marcas devem trabalhar para que comuniquem cada vez mais perto da realidade. Assim, constroem sua narrativa e relação com o público baseadas nos diversos tipos de corpos.

As redes sociais também facilitaram a comunicação das marcas menores que conseguem atingir um público maior. Ao mesmo tempo que dificultaram para as grandes marcas, pois um anúncio com alcance global pode repercutir tanto positiva quanto negativamente, de acordo com as diferenças culturais e influenciar na adesão do público à marca. Além disso, à medida que o consumidor espera que a marca demonstre cada vez mais verdade e representatividade em suas campanhas, isso deve passar a fazer parte do dia a dia e dos bastidores das marcas e não apenas das ações de comunicação, uma vez que a internet deu acesso a informações que antes não eram de conhecimento geral. 
Considerando essas questões, retorna-se ao objetivo geral do presente artigo que era avaliar se a publicidade de moda pode desconstruir padrões estéticos violentos e coercitivos. 0 objetivo foi atingido com o entendimento de que ao abordarem a diversidade, as marcas atraem um novo tipo de público, que antes não era representado e, portanto, não se sentia parte do que elas significavam em seus produtos. A Savage X Fenty, por exemplo, mesmo não abrangendo literalmente todos os tipos de corpos, pois ainda possui uma limitação em relação aos tamanhos que oferece, alcança mais pessoas e biotipos que as marcas que não celebram a diversidade. Já a Natura e suas campanhas a favor da inclusão e da diversidade podem ser consideradas como a difusão de um 'novo padrão' de beleza e, principalmente, de comunicação. Por ser uma marca de cosméticos ela quebra determinados padrões de beleza ultrapassados, mas mantém a ideia do cuidado com o corpo relacionado ao consumo de produtos. No entanto, não se deve perder de vista que determinadas campanhas, acima de celebrar a diversidade, buscam ganhos econômicos e, mais do que um posicionamento ideológico arriscado e corajoso, têm os ganhos pensados e calculados a partir desses discursos e a abrangência de públicos-alvo.

Deve-se considerar que os estereótipos são a solidificação dos discursos em vigência na sociedade e podem sofrer transformações de acordo com as mudanças sociais em curso. Quando um estereótipo é modificado, deixa de ser um padrão para se tornar um novo arquétipo. Ainda que em geral a publicidade contemporânea de moda se proponha a quebrar paradigmas, a base essencial do funcionamento e lucro das empresas é a venda, portanto precisam se adequar às demandas do público-alvo. Assim, a publicidade ainda mantém algumas características em comum com os padrões considerados ultrapassados, para que não perca de vez suas características, e consequentemente, não deixe de vender para amplos públicos. As marcas precisam se posicionar, porém as mudanças acontecem aos poucos, à medida que os consumidores mudam suas maneiras de pensar e se libertam de certos padrões preestabelecidos.

Sem desconsiderar a importância da representatividade de grupos marginalizados e fora dos padrões estabelecidos, a atenção crítica deve questionar se a divulgação e promoção de anúncios sob a ótica da diversidade não influenciaria no surgimento de um novo padrão de apelo comercial, mais pautado no lucro das empresas do que de fato no desejo 
de promoverem a inclusão dos públicos. Porém, mesmo que o objetivo final das empresas e marcas seja converter a publicidade em vendas, o fato de o público ver e ter acesso as campanhas com mais inclusão e representatividade contribui com a promoção da diversidade.

\section{Referências}

BAUDRILLARD, Jean. A sociedade de consumo. Lisboa: Edições 70, 2003.

BRAGA, João. História da moda: uma narrativa. São Paulo: Anhembi Morumbi, 2004.

BRANDES, Aline Zandonadi; SOUZA, Patricia de Mello. Corpo e Moda pela Perspectiva do Contemporâneo. Revista Científica de Design, Londrina, v. 3, n. 12, jul. 2012.

BRASIL, Bbc News. 'Creme para embranquecer pele' coloca Nivea no centro de polêmica em países da África. 2017. Disponível em:

<https://www.bbc.com/portuguese/salasocial-41686093 >. Acesso em: 25.05.2021.

BRETON, David Le. Adeus ao corpo: Antropologia e sociedade. Campinas: Papirus, 2003.

CHITAS, Irina. Livro de História: Victoria's Secret. 2016. Disponível em: < https://www.vogue.pt/livro-de-historia-victoria-s-secret >. Acesso em: 25.05.2021.

CORBIN, Alain; COURTINE, Jean-Jacques; VIGARELLO, Georges (orgs.). História do corpo: as mutações do olhar, o século XX. Petrópolis: Vozes, 2008. Tradução e revisão: Ephraim Ferreira Alves.

. Prefácio à História do corpo. IN CORBIN, Alain, COURTINE, Jean-Jacques, VIGARELLO, Georges. História do corpo: Da Renascença às luzes. Tradução de Lúcia M.E.Orth; revisão da tradução Ephrain Ferreira Alves - 4. Ed. Petrópolis, RJ: Vozes, 2010. (Volume dirigido por Georges Vigarello), p. 7-13.

DAILY PR Africa. Nivea's 'visibly fairer skin'; lessons for communicators. 2017. Disponível em: < https://www.dailyprafrica.com/niveas-visibly-fairer-skin-lessonscommunicators/ > Acesso em: 25.05.2021.

DEL PRIORE, Mary. Corpo a corpo com a mulher. Pequena história das transformações do corpo feminino no Brasil. São Paulo: SENAC, 2000.

FOUCAULT, Michel. Vigiar e Punir: o nascimento da prisão; tradução de Raquel Ramalhete. 40aㅡ ed. Petrópolis, RJ : Vozes, 2012.

GARDNER, Abby. Ed Razek, the Man Behind the Victoria's Secret Fashion Show, Is Leaving the Company. 2019. Disponível em: < https://www.glamour.com/story/edrazek-leaves-victorias-secret >. Acesso em: 25.05.2021. 
GOFFMAN, Erving. Estigma: notas sobre a manipulação da identidade deteriorada. 4 . ed. São Paulo: Editora LTC, 2004.

GOLDENBERG, Mirian (Org.). 0 corpo como capital: estudos sobre gênero, sexualidade e moda na cultura brasileira. São Paulo: Estação das Letras e Cores. 2010.

Invisíveis ou inclassificáveis?: Gênero, corpo e envelhecimento na cultura brasileira. In: MESQUITA, Cristiane; CASTILHO, Kathia (Org.). Corpo, Moda e Ética: pistas para uma reflexão de valores. São Paulo: Estação das Letras e Cores, 2011. p. 59-61.

HONORATO, Thainan. Brasil lidera ranking de cirurgia plástica entre jovens. 2018. Disponível em: < http://www2.cirurgiaplastica.org.br/2018/06/07/brasil-lideraranking-de-cirurgia-plastica-entre-jovens/ >. Acesso em: 25.05.2021.

ISAPS (Ed.). Mais recente estudo internacional demonstra crescimento mundial em cirurgia estética. 2018. Disponível em: < https://www.isaps.org/wpcontent/uploads/2018/11/2017-Global-Survey-Press-Release-br.pdf > . Acesso em: 25.05.2021.

LIPOVETSKY, Gilles. Sedução, publicidade e pós-modernidade. Revista Famecos, Porto Alegre, v. 7, n. 12, p.7-13, jun. 2000.

O império do efêmero: A moda e seu destino nas sociedades modernas. São Paulo: Companhia das Letras, 2009.

LOBO, Renato Nogueirol; LIMEIRA, Erika Thalita Navas Pires; MARQUES, Rosiane do Nascimento. História e sociologia da moda: evolução e fenômenos culturais. São Paulo: Érica, 2014.

LOPES, Michelle Aparecida Pereira. DA MODA DO CORPO AO CORPO DA MODA: DESCONTINUIDADES DISCURSIVAS SOBRE O SUJEITO “GORDO”. In: COLÓQUIO DA ALED, 5., 2014, São Carlos. Anais do V Colóquio da Aled. São Carlos: Universidade Federal de São Carlos, 2014.

LYSARDO-DIAS, Dylia. A Construção e a desconstrução de estereótipos pela publicidade brasileira. In: MACHADO-BORGES, Thaïs (Ed.). Passando dos limites? Mídia e transgressão - Casos brasileiros. Estocolmo: Institute Of Latin American Studies, 2007.

OLIVEIRA, Marcelo Gomes de et al. O EU, O CORPO E A MODA: REFLEXOS DOS ANOS 80. In: CONGRESSO BRASILEIRO DE INICIAÇÃO CIENTÍFICA EM DESIGN E MODA, 2., 2015, Londrina. Anais. Londrina: Universidade Estadual de Londrina, 2015.

POLLINI, Denise. A moda do século XX. In: POLLINI, Denise. Breve história da moda. São Paulo: Claridade, 2007. p. 50-82.

PRODANOV, Cleber Cristiano; FREITAS, Ernani Cesar de. Metodologia do trabalho científico: Métodos e Técnicas da Pesquisa e do Trabalho Acadêmico. Novo Hamburgo: Universidade Feevale, 2013. 
PROMOVIEW. Natura Todo dia questiona rótulos em mulheres. 2019. Disponível em:

< https://www.promoview.com.br/categoria/publicidade/natura-tododia-questionarotulos-em-mulheres.html >. Acesso em: 25.05.2021.

RIHANNA. SAVAGE X Fenty Show. Nova York: Fenty Films, 2019. Som, color.

SANT'ANNA, Denise B. de. História da beleza no Brasil. São Paulo: Contexto, 2014.

SANTOS, Rogério. Fotografias de Oliviero Toscani. Site Indústrias Culturais, 2007. Disponível em < https://industrias-

culturais.hypotheses.org/category/publicidade/page/3 > Acesso em 25.05.2021.

SCAGLIUSI, Fernanda Baeza; SANTOS, Roberto Manoel dos. Beleza.jpg: borrando os limites da realidade. In: MESQUITA, Cristiane; CASTILHO, Kathia (Org.). Corpo, Moda e Ética: pistas para uma reflexão de valores. São Paulo: Estação das Letras e Cores, 2011.

SILVA, Maria Lídia de Abreu; TAQUETTE, Stella Regina; ABOUDIB, José Horácio Costa. Transtorno dismórfico corporal: contribuições para o cirurgião plástico. Revista Brasileira de Cirurgia Plástica, Rio de Janeiro, v. 28, n. 3, p.499-506, 2013.

SILVA, Keliny. A Representatividade do Corpo na Publicidade Brasileira: Os Estereótipos de Beleza x 0 Corpo Diferente. In: CONGRESSO DE CIêNCIAS DA COMUNICAÇÃO NA REGIÃO NORDESTE, 16., 2014, João Pessoa. Anais: Universidade Federal de Pernambuco, 2014.

SILVA, Sergio Damasceno. Natura cria campanha de diversidade e internet reage. 2019. Disponível em: < https://www.meioemensagem.com.br/home/comunicacao/2019/05/14/natura-criacampanha-de-diversidade-e-internet-reage.html >. Acesso em: 25.05.2021.

SOCIEDADE BRASILEIRA DE CIRURGIA PLÁSTICA. Estudo mostra as taxas mundiais de mortalidade na lipoenxertia glútea. 2017. Disponível em: < http://www.sbcpsp.org.br/artigos/estudo-mostra-as-taxas-mundiais-de-mortalidade-na-lipoenxertiaglutea/ >. Acesso em: 25.05.2021.

SONTAG, Susan. Sobre fotografia. São Paulo: Companhia das Letras, 2004.

VIGARELLO, Georges. História da Beleza: o corpo e a arte de se embelezar, do renascimento aos dias de hoje. Rio de Janeiro: Ediouro, 2006.

VOGUE. Savage x Fenty: Rihanna lança linha de lingerie. 2018. Disponível em: < https://vogue.globo.com/moda/noticia/2018/05/savage-x-fenty-rihanna-lanca-linhade-lingerie.html > . Acesso em: 25.05.2021. 